\title{
ПЕДАГОГІЧНІ УМОВИ ФОРМУВАННЯ ГОТОВНОСТІ МАЙБУТНІХ УЧИТЕЛІВ АНГЛІЙСЬКОЇ МОВИ ПОЧАТКОВИХ КЛАСІВ ДО ЗАСТОСУВАННЯ ІНТЕРАКТИВНИХ ТЕХНОЛОГІЙ У ПРОФЕСІЙНІЙ ДІЯЛЬНОСТІ
}

\author{
Міхаіл Другов \\ кандидат педагогічних наук, старший викладач \\ кафедри теорії і практики початкової освіти \\ ДВНЗ «Донбаський державний педагогічний університет» \\ Слов'янськ, Україна \\ ORCID ID 0000-0001-6252-9602 \\ michaeldrugov@gmail.com
}

\begin{abstract}
Анотація. У статті виокремлено та проаналізовано педагогічні умови формування готовності майбутніх учителів англійської мови початкових класів до застосування інтерактивних технологій у професійній діяльності. Автором представлено детальний аналіз поняття «технологія», а також визначено сутність поняття «інтерактивна технологія». Представлено відмінність методики від технології. Доведено, що до умов реалізації зазначеного феномена належать: формування мотивації студентів до використання інтерактивних технологій у майбутній професійній діяльності; збагачення навчального змісту психолого-педагогічних дисциплін інформацією щодо сутності, змісту, структури та специфіки використання інтерактивних технологій у професійній діяльності майбутнього вчителя англійської мови початкових класів; організація взаємодії суб'єктів навчального процесу на основі паритетного діалогу; спрямування студентів до самоосвіти і педагогічного самовдосконалення шляхом аналізу власного досвіду використання інтеракцій на практиці. Автором надано детальний опис кожної умови та шляхи їхньої реалізації.
\end{abstract}

Ключові слова: підготовка майбутніх учителів початкових класів; педагогічні умови; інтерактивні технології; професійна діяльність; готовність; англійська мова.

Постановка проблеми в загальному вигляді. Процеси глобалізації, інтеграції та посилення міжнародних зв'язків України ставлять нові вимоги перед системою освіти загалом і перед професійною підготовкою майбутніх учителів зокрема. Ці вимоги висвітлено в низці нормативних документів: законах України «Про освіту» (2017р.), «Про вищу освіту» (2014р.), Концепції «Нова українська школа» (2016р.), Державному стандарті початкової освіти (2018 р.), Національній стратегії розвитку освіти в Україні на період до 2021 року (2013 р.). 3 огляду на такі вимоги в закладах вищої освіти відбувається перехід від пасивних до активних технологій навчання. Однією 3 ключових $\epsilon$ інтерактивна технологія, яка сфокусована на реалізації особистісно орієнтованого підходу в навчанні та сприяє активній взаємодії всіх учасників освітнього процесу. Інтерактивні технології навчання, на думку вчителів та науковців, є засобом впровадження інноваційних технологій у підготовку майбутніх учителів. 
Педагогічні умови формування готовності майбутніх учителів англійської мови початкових класів до застосування інтерактивних технологій у професійній діяльності

Особливого значення інтерактивні технології набувають у контексті підготовки майбутнього вчителя англійської мови, під якою розуміють безпосередній діалог між учасниками освітнього процесу. Під час вивчення іноземної мови, застосовуючи інтерактивні технології, студентами усвідомлюється цінність інших людей, інших культур, думок та інтересів, формується потреба в спілкуванні як рідною, так і іноземною мовою. Це змушує науковців присвячувати свої дослідження пошуку ефективних шляхів підвищення рівня фахової підготовки майбутніх учителів, створювати умови для їхнього фахового зростання.

Аналіз останніх досліджень і публікацій. Різні аспекти фахової підготовки майбутніх учителів початкових класів загалом та англійської мови зокрема висвітлено в дослідженнях багатьох вітчизняних i закордонних науковців. Загальнодидактичні питання запровадження інтерактивного навчання як освітньої технології докладно вивчають Л. Коваль, О. Пометун, Л. Пироженко, Г. Сиротенко та ін. С. Амеліна вивчає питання доцільності впровадження європейських освітніх стандартів у систему іншомовної освіти України, Л. Гапоненко досліджує проблему формування готовності студентів до іншомовного спілкування.

Головним завданням підготовки майбутніх учителів англійської мови початкових класів $є$ зосередження уваги на практичному володінні іноземною мовою, яке передбачає організацію іншомовної мовленнєвої взаємодії та формування не лише лінгвістичної компетентності (знання фонетичного, лексичного, граматичного матеріалу та вміння використовувати його в різних мовленнєвих ситуаціях), а й формування вмінь організації навчально-виховного процесу в початковій школі через запровадження педагогічних інновацій інтерактивного типу. Розвиток вищої педагогічної освіти в Україні на засадах Євроінтеграції вимагає від майбутніх учителів англійської мови засвоєння сучасних напрямів розвитку теорії мовної комунікації, формування вмінь використовувати мовні механізми і моделі створення та сприйняття іноземної мови в спілкуванні [1].

Відома дослідниця в галузі професійно-методичної підготовки майбутніх учителів англійської мови С. Ніколаєва наголошує, що професійна підготовка вчителів іноземних мов включає в себе володіння іноземною мовою як засобом усної та писемної комунікації в усіх сферах спілкування, а також як засобом педагогічної діяльності в різних умовах з урахуванням цілей навчання, вікових особливостей та мовної підготовки [6, с. 242]. Тому ціла низка науковців особливу увагу зосереджує на формуванні професійно-методичної компетентності майбутнього вчителя іноземної мови (Л. Калініна, О. Місечко, С. Роман, I. Самойлюкевич, О. Тарнопольський).

Науковці також відзначають, що майбутні вчителі мають бути готові до застосування інноваційних технологій інтерактивного характеру. Переваги використання інтерактивних технологій аргументували С. Кашлєв, О. Комар, 
Педагогічні умови формування готовності майбутніх учителів англійської мови початкових класів до застосування інтерактивних технологій у професійній діяльності

I. Мельничук, I. Підласий, Л. Пироженко, Н. Побірченко, М. Скрипник, В. Трайнєв та інші. Інноваційні підходи до вивчення іноземних мов $є$ предметом дослідження таких закордонних дослідників: Г. Дудіні (G. Dudeney), Н. Хоклі (N. Hockly), Д. Нунан (D. Nunan), Дж. Річардс (J. Richards), В. Ренандья (W. Renandya). P. Томас (R. Thomas), C. Ведемейер (C. Wedemeyer). Дж. Moip (G. Moir), Д. Ялден (D. Yalden) та ін.

Усе зазначене вище викликає потребу наукового обгрунтування формування готовності молоді до здійснення професійної педагогічної діяльності із застосуванням інтерактивних технологій навчання.

Формулювання цілей статті. Метою статті $є$ виокремити та обгрунтувати педагогічні умови формування готовності майбутніх учителів англійської мови початкових класів до застосування інтерактивних технологій у своїй професійній діяльності, а також показати можливості інтерактивних технологій як засобу підвищення якості підготовки майбутнього вчителя.

Методика дослідження. Для досягнення поставленої мети переважно було використано такі теоретичні методи: аналіз загальнопедагогічної та методичної літератури i навчально-методичних матеріалів для визначення реального стану готовності майбутніх учителів англійської мови початкових класів до використання інтерактивних технологій у професійній діяльності, а також синтез, абстрагування, узагальнення, прогнозування, що дали можливість порівнювати і зіставляти наявні теоретичні та практичні підходи до розуміння особливостей підготовки майбутніх учителів початкових класів до застосування інтерактивних технологій у їхній професійній діяльності.

Результати дослідження. Поняття «технологія» з'явилося порівняно недавно в педагогічній науці. Однак тривалий час педагоги ставилися скептично до цього терміна. Сьогодні воно $\epsilon$ широко розповсюдженим у педагогіці. Проте дискусії щодо визнання технологій навчання та виховання як необхідного інструмента, яким має володіти кожен учитель, тривають і нині. Серед вітчизняних педагогів розробкою теоретичних питань розвитку освітніх технологій займаються О. Пєхота, І. Дичківська, О. Падалка, В. Лозова, В. Паламарчук, А. Нісімчук, А. Фурман, В. Шаталов, С. Сисоєва, О. Любарська, О. Олексюк та ін.

Історично поняття «технологія» пов'язане з розвитком науково-технічного процесу. У 30-ті роки XX ст. у США розпочалася технологічна революція, із розвитком якої в школи поступово почали впроваджуватися аудіовізуальні, а також інші технічні засоби навчання. У використанні цих технологічних засобів американські дослідники вбачали головний шлях підвищення ефективності навчання. Упродовж 30-80-х років XX ст. це поняття еволюціонувало від «технологій в освіті» до «освітніх технологій». Так, «освітні технології» - це не просто дослідження у сфері застосування технічних засобів навчання, а дослідження $з$ метою виявлення принципів і розробки прийомів оптимізації навчального процесу шляхом аналізу факторів, що підвищують ефективність 
Педагогічні умови формування готовності майбутніх учителів англійської мови початкових класів до застосування інтерактивних технологій у професійній діяльності

навчання, за допомогою конструювання і використання прийомів і матеріалів, а також оцінки використаних методів [4, с. 25].

Більшість вітчизняних дослідників (І. Дичківська, О. Пехота та ін.) погоджуються 3 таким розмежуванням цих понять, перше 3 яких пов'язане 3 застосуванням технічних засобів навчання в педагогічному процесі, а друге -3 розвитком педагогічної теорії. О. Пєхота також наголошує на необхідності об'єднання цих двох дефініцій, тобто системного підходу до освітніх питань [7, с. 13 - 14]. Системний підхід до освітнього процесу є пріоритетним у визначенні ЮНЕСКО, відповідно до якого «педагогічна технологія» є системним методом створення, використання та визначення всього процесу викладення і засвоєння знань, з урахуванням технічних і людських ресурсів, а також їхня взаємодія 3 метою оптимізації форм навчання [4, с. 26].

У сучасній педагогічній літературі технології навчання наближені до методики викладання окремих предметів. Метою такої технології $\epsilon$ алгоритмізація засвоєння конкретного навчального матеріалу, теми, поняття тощо. Проте, на думку дослідників (О. Пометун, Л. Пироженко, С. Сисоєвої), технологію від методики відрізняють дві характеристики: гарантія кінцевого результату й проектування майбутнього навчального процесу. Педагогічна технологія - набір процедур, які привносять щось нове в професійну діяльність учителя і гарантують кінцевий запланований результат [8, с. 42]. Крім того, під час технологічного навчання усувається безліч «якщо»: якщо талановитий учитель, талановиті діти, багата школа. Методика формується як результат узагальнення досвіду або впровадження нових засобів. Технологія ж проектується, виходячи з конкретних умов, та орієнтується на заданий, а не на передбачуваний результат [8, с. 43]. Технологія, на відміну від методики, не допускає варіативності, із неї не можна вилучати елементи. Технологічний підхід не допускає пошукової діяльності, спроб, тут не може бути помилок. Для технологічного навчання обов'язковим є постійний зворотній зв'язок, внесення виправлення та змін у подальшу діяльність.

Науковці також наголошують, що головною відмінністю технології від методики є її алгоритмізованість. Алгоритм - це точний однозначний припис про виконання у визначеній послідовності операцій (дій), що ведуть до розв'язання поставлених завдань. Проте якщо алгоритм передбачає точну репродукцію дій, то педагогічна технологія враховує і припускає творчість як вчителя, так і учнів $[3$, с. 86].

Входження до складу технології сукупності дій та операцій, а також алгоритмізованість цих дій виявили необхідність їхнього чіткого структурування. Г. Селевко визначив структуру педагогічної технології:

а) концептуальна основа;

б) змістова частина навчання:

- цілі навчання - загальні та конкретні; 
Педагогічні умови формування готовності майбутніх учителів англійської мови початкових класів до застосування інтерактивних технологій у професійній діяльності

- зміст навчального матеріалу;

в) процесуальна частина - технологічний процес:

- організація навального процесу;

- методи і форми навчальної діяльності учнів;

- методи і форми діяльності вчителя;

- діяльність учителя щодо керівництва процесом засвоєння знань

учнями;

- діагностика навчального процесу.

Перейдемо до визначення сутності інтерактивної технології. Як стверджують дослідники (О. Пометун, Л. Пироженко, С. Сисоєва), інтерактивною технологією навчання є така організація навчального процесу, за якої кожен учень бере участь у колективному, заснованому на взаємодії та спілкуванні всіх його учасників, процесі навчального пізнання. Інтерактивна технологія навчання містить такі головні компоненти, що не заперечать загальноприйнятій структурі технології за Г. Селевко: чітко сплановані цілі навчання - зрозумілий якісний і кількісний очікуваний результат процесу у вигляді навчальних досягнень учнів, а саме: передбачуваного рівня засвоєння навчального змісту; спеціально відібраний і структурований зміст навчання; інтерактивні форми, методи i прийоми, за допомогою яких організоване навчання і стимулюється активна діяльність учнів; адекватні цілям, формам і методам засоби навчання; розумові і навчальні дії та процедури, за допомогою яких учні можуть досягти запланованих результатів, представлені у вигляді системи пізнавальних завдань; організаційні та психолого-педагогічні умови, що дозволяють ефективно спланувати та реалізувати інтерактивне навчання [3, с. 88].

Поняття «інтерактивні технології навчання» багато в чому збігається 3 поняттям «інтерактивний метод», а інтерактивні методи визначають як способи цілеспрямованої міжсуб'єктної взаємодії вчителя i учнів зі створення оптимальних умов для свого розвитку. Головною ознакою інтерактивних методів $\epsilon$ «взаємодія», під якою розуміють безпосередню міжособистісну комунікацію, найважливішою особливістю якої є здатність людини «приймати роль іншого», уявляти, як іiі сприймає партнер по спілкуванню або група, i відповідно інтерпретувати ситуацію і конструювати власні дії.

Інтерактивні технології набувають високої значущості в навчанні іноземних мов. Метою застосування інтерактивних технологій у процесі вивчення іноземної мови є створення комфортних умов навчання, у яких усі учасники освітнього процесу взаємодіють між собою. На заняттях створюється можливість обговорення різноманітних проблем, доведення, аргументування власного погляду, тобто відбувається взаємодія викладача і студента, яка орієнтує особистість на розвиток ऑii творчих і розумових здібностей та комунікативних навичок [2]. 
Педагогічні умови формування готовності майбутніх учителів англійської мови початкових класів до застосування інтерактивних технологій у професійній діяльності

Зазначена низка ознак інтерактивних технологій дозволяє говорити про інноваційність цієї педагогічної технології порівняно з традиційними методами організації навчального процесу. Тому широке іiі запровадження в освітній процес сучасних закладів загальної середньої освіти привертає серйозну увагу до цього явища 3 боку працівників педагогічних 3ВО, бо лише послідовна цілеспрямована робота 3 навчання майбутніх учителів дійсно допоможе їм опанувати цією педагогічною технологією та підготуватися до іiї застосування в подальшій професійній діяльності. Це стане можливим за умов, якщо майбутні вчителі англійської мови початкових класів оволодіють знаннями, уміннями та навичками використання інтерактивних технологій. Тому виникає необхідність виокремити та обгрунтувати педагогічні умови формування готовності майбутніх учителів англійської мови початкових класів до використання інтерактивних технологій у професійній діяльності [2].

Для того щоб окреслити низку ефективних педагогічних умов формування готовності майбутніх учителів до застосування інтерактивних технологій у професійній діяльності, було проаналізовано наукові доробки відомих вітчизняних науковців: Г. Кривчикової (педагогічні умови інтерактивного навчання писемного мовлення майбутніх учителів англійської мови), Н. Павленко (педагогічні умови підготовки майбутнього вчителя початкових класів до використання інтерактивних педагогічних технологій), А. Вереснєва (педагогічні умови підготовки майбутніх учителів іноземних мов до застосування особистісно орієнтовних технологій навчання), Л. Морської (педагогічні умови підготовки майбутнього вчителя іноземних мов до використання інформаційних технологій у навчанні учнів) [5].

Аналіз науково-педагогічної літератури, а також узагальнення власного педагогічного досвіду дозволяють стверджувати, що ефективному застосуванню інтерактивних технологій у професійній діяльності вчителя англійської мови початкових класів забезпечують такі умови:

1) формування мотивації студентів до використання інтерактивних технологій у майбутній професійній діяльності вчителя;

2) збагачення навчального змісту психолого-педагогічних дисциплін інформацією щодо сутності, змісту, структури та специфіки використання інтерактивних технологій у професійній діяльності майбутнього вчителя англійської мови початкових класів;

3) організація взаємодії суб’єктів навчального процесу на основі паритетного діалогу;

4) спрямування студентів до самоосвіти i педагогічного самовдосконалення шляхом аналізу власного досвіду використання інтеракцій на практиці.

Перейдемо до детального розгляду кожної із зазначених педагогічних умов. 
Педагогічні умови формування готовності майбутніх учителів англійської мови початкових класів до застосування інтерактивних технологій у професійній діяльності

Для формування мотивації студентів до застосування інтерактивних технологій слід сфокусуватися на усвідомленні ними необхідності опанування теоретичних знань стосовно сутності інтерактивних технологій, урахування їхніх особливостей в організації занять з іноземної мови в початковій школі, потреби оволодіння методичними вміннями та навичками, розвитку рефлексивних здібностей студента, емоційності навчання [5, с. 110].

Особливо науковці наголошують на створенні позитивного емоційного навчального середовища, що сприяє формуванню таких характеристик:

1) позитивного ставлення студентів до використання інтерактивних технологій у професійній діяльності, що виявляється в ознаках поведінки студентів, а саме: активне залучення до навчальної діяльності, ефективне сприймання пізнавального матеріалу, зосередженість на інформації, що зацікавила, відсутність відволікань, домінування мимовільної уваги тощо;

2) вияв активності студентів у позанавчальний час: обговорення 3 викладачем проблем застосування інтерактивних технологій, висловлювання власних думок із тієї чи тієї теми, щоб уточнити можливості використання інтерактивних технологій у майбутній професійній діяльності;

3) потреба в самоаналізі, усвідомленні необхідності самоосвіти [5, с. 113].

Реалізація другої умови вимагає від студента наявності стійких знань щодо сутності, змісту, структури та специфіки запровадження інтерактивних технологій в освітній процес початкової школи. Ця умова вимагає формування когнітивного компонента готовності майбутніх учителів англійської мови початкових класів до використання інтерактивних технологій і розширення обізнаності студентів через збагачення змісту навчальних дисциплін «Методика навчання англійської мови» та «Практика усного та писемного мовлення (англійська мова)» новим навчальним матеріалом щодо можливостей використання інтерактивних технологій у навчанні молодших школярів англійської мови.

Отримані знання студенти можуть практично апробувати під час обговорень, аналізуючи позитивні і негативні сторони різних інтерактивних технологій. Тому третя педагогічна умова полягає в організації суб'єктсуб'єктної взаємодії учасників освітнього процесу на основі паритетного діалогу [5, с. 121 - 122]. Зокрема, реалізація третьої педагогічної умови спрямовувалось на те, щоб студенти зрозуміли концептуальну ідею діалогічності в навчанні учнів іноземної мови, яка полягає в баченні діалогу як невід'ємного компонента внутрішнього позитивного змісту свободи особистості.

Крім того, активна взаємодія викладача та студентів на засадах паритетного діалогу сприяє формуванню спеціальних професійних умінь, зокрема комунікативних. Для майбутніх учителів важливо володіти прийомами педагогічного спілкування, його тактикою та стратегією. Зауважимо, що для реалізації третьої умови, увагу студентів слід зосередити на тому, що в освітньому процесі інтерактивні технології мають застосовуватись таким чином, 


\section{М. ДРУГОВ}

Педагогічні умови формування готовності майбутніх учителів англійської мови початкових класів до застосування інтерактивних технологій у професійній діяльності

щоб сприяти забезпеченню всіх видів спілкування. У процесі такого спілкування вчитель стає педагогом-фасилітатором, радником, помічником учнів під час оволодіння іноземною мовою.

Останньою із зазначених умов $є$ спрямування студентів до самоосвіти та педагогічного самовдосконалення, для реалізації якої слід створити передумови для рефлексії власного досвіду та готовності до використання інтерактивних технологій у майбутній професійній діяльності.

Результат самоаналізу зумовлює усвідомлення студентами ролі та місця інтерактивних технологій серед інших технологій навчання іноземної мови в початковій школі, їхнього зв'язку і взаємовпливу: розуміння перспектив і цілей професійного саморозвитку в напрямі опанування інноваційними методами інтерактивних технологій, що постійно оновлюються; формування спрямованості майбутнього педагога на подолання перешкод, що виникають у процесі впровадження навчальних інтеракцій на уроках іноземної мови в початковій школі. Слід ураховувати, що педагогічний самоаналіз буде продуктивним лише за умови наявності самостійності та внутрішньої мотивації студента, що вказує на те, що педагогічні умови дослідження реалізуються комплексно [5, с. 126].

Висновки 3 дослідження й перспективи подальших розвідок у цьому напрямі. Отже, формування готовності майбутніх учителів англійської мови початкових класів до використання інтерактивних технологій в професійній діяльності відбувається через запровадження комплексу заходів, що мають створити умови, реалізація яких сприяє оптимізації процесу професійної підготовки майбутніх учителів і зокрема формування досліджуваного феномена.

Перспективними вбачаємо подальші розвідки щодо розробки методичних рекомендацій до курсу «Методика навчання англійської мови» із зазначенням особливостей використання інтерактивних технологій під час вивчення мовного матеріалу, а також у процесі формування комунікативної компетентності молодших школярів у всіх видах мовленнєвої діяльності.

\section{СПИСОК ВИКОРИСТАНИХ ДЖЕРЕЛ}

1. Бескорса, О.С. (2018). Компаративний аналіз традиційних та інноваційних тенденцій викладання англійської мови у ВНЗ. Професіоналізм педагога: теоретичні $и$ методичні аспекти, 7, 62-72.

2. Козаченко, В. І. (2014). Використання інтерактивних технологій у підготовці майбутніх учителів іноземних мов. Педагогічні науки, 117, 62-69.

3. Комар, О.А. (2011). Теоретичні та методичні засади підготовки майбутніх учителів початкової школи до застосування інтерактивної технології. (Дис. д-ра пед. наук). Умань, Україна.

4. Кукушкин, В. С. (Ред.). (2004). Педагогические технологии: учебное пособие для студентов педагогических специальностей. Москва, Россия: ИКЦ «МарТ».

5. Липчанко-Ковальчик, О. В. (2016). Підготовка майбутніх бакалаврів-філологів до використання інтерактивних технологій у професійній діяльності. (Дис. канд. пед. наук). Рівне, Україна.

Професіоналізм педагога: теоретичні й методичні аспекти. - Вип. 8. - Слов'янськ, 2018. 
Педагогічні умови формування готовності майбутніх учителів англійської мови початкових класів до застосування інтерактивних технологій у професійній діяльності

6. Ніколаєва, С. Ю. (2002). Методика викладання іноземних мов у середніх навчальних закладах. Київ, Україна: Ленвіт.

7. Пометун, О. І. і Пироженко, Л. В. (2004). Сучасний урок: інтерактивні технології навчання. Київ, Україна: А.С.К.

8. Сисоєва, С. О. (Ред.). (2001). Педагогічні технологї̈ у неперервній професійній освіті. Київ, Україна.

\title{
ПЕДАГОГИЧЕСКИЕ УСЛОВИЯ ФОРМИРОВАНИЯ ГОТОВНОСТИ БУДУЩИХ УЧИТЕЛЕЙ АНГЛИЙСКОГО ЯЗЫКА НАЧАЛЬНЫХ КЛАССОВ К ИСПОЛЬЗОВАНИЮ ИНТЕРАКТИВНЫХ ТЕХНОЛОГИЙ В ПРОФЕССИОНАЛЬНОЙ ДЕЯТЕЛЬНОСТИ
}

\author{
Михаил Другов \\ кандидат педагогических наук, старший преподаватель кафедры теории и \\ практики начального образования \\ ГВУЗ «Донбасский государственный педагогический университет» \\ г. Славянск, Украина \\ ORCID ID 0000-0001-6252-9602 \\ michaeldrugov@gmail.com
}

\begin{abstract}
Аннотация. В статье выделены и проанализированы педагогические условия формирования готовности будущих учителей английского языка начальных классов к применению интерактивных технологий в профессиональной деятельности. Автором представлен подробный анализ понятия «технология», а также определена сущность понятия «интерактивная технология». Представлено отличие методики от технологии. Доказано, что к условиям реализации указанного феномена относятся: формирование мотивации студентов к использованию интерактивных технологий в будущей профессиональной деятельности; обогащение учебного содержания психолого-педагогических дисциплин информацией о сущности, содержании, структуре и специфике использования интерактивных технологий; организация взаимодействия субъектов учебного процесса на основе паритетного диалога; стремление студентов к самообразованию и педагогическому самосовершенствованию путем анализа собственного опыта использования интеракций на практике. Автором предоставлено детальное описание каждого условия и пути их реализации.
\end{abstract}

Ключевые слова: подготовка будущих учителей начальных классов; педагогические условия; интерактивные технологии; профессиональная деятельность; готовность; английский язык.

\section{PEDAGOGICAL CONDITIONS OF DEVELOPING FUTURE PRIMARY SCHOOL ENGLISH TEACHERS' READINESS TO IMPLEMENT INTERACTIVE TECHNOLOGIES INTO THEIR PROFESSIONAL ACTIVITIES}

\author{
Mikhail Druhov \\ Candidate of Pedagogical Sciences, Senior Lecturer of Primary \\ Education Theory and Practice Department \\ SHEE "Donbas State Pedagogical University"
}

(C) ДВНЗ «Донбаський державний педагогічний університет» 


\title{
М. ДРУГОВ
}

Педагогічні умови формування готовності майбутніх учителів англійської мови початкових класів до застосування інтерактивних технологій у професійній діяльності

\section{ORCID ID 0000-0001-6252-9602 \\ michaeldrugov@gmail.com}

\begin{abstract}
The issue of implementing interactive technologies while teaching foreign languages in primary school is relevant as it corresponds to new educational standards both in Ukraine and abroad. Implementation of interactive technologies contributes to deeper understanding of other peoples, their culture, opinions. They are essential for improving the level of teachers' professional training.

A great number of scientists devote their researches to developing professional and methodological competence of future English teachers (L. Kalinina, O. Misechko, S. Roman, I. Samoiliukevych, O. Tarnopolskyi). The purpose of the article is to single out and characterize the pedagogical conditions of developing future primary school English teachers' readiness to implement interactive technologies in their professional activities. The author presents the detailed analysis of the concept "technology". He points out how it is different from the methodology. The essence of the concept "interactive technology" is also disclosed.

The following pedagogical conditions are thought to be essential for developing future primary school English teachers' readiness to implement interactive technologies: developing students' motivation to use interactive technologies in their future professional activities; enriching learning content of psychological and pedagogical disciplines with the information about essence, content, structure and features of using interactive technologies in professional activities; organizing the subject-subject interaction between all the participants of learning process; stimulating students to self-education and pedagogical self-improvement through analyzing their own experience of implementing interactives in the practice. The author gives the detailed description of each condition and explains the ways of their realization. It is emphasized that all these conditions should be implemented as a complex phenomenon.
\end{abstract}

Key words: future primary school teachers' training; pedagogical conditions; interactive technologies; professional activities; readiness; English teaching.

\section{REFERENCES (TRANSLATED AND TRANSLITERATED)}

1. Beskorsa, O. S. (2018). Comparative analysis of traditional and innovative trends of teaching English at tertian institutions. Profesionalizm pedahoha: teoretychni I metodychni aspekty, 7, 62-72.

2. Kozachenko, V. I. (2014). Implementing interactive technologies in future foreign language teachers' training. Pedahohichni nauky, 117, 2-69.

3. Komar, O. A. (2011). Theoretical and methodological foundations of future primary school teachers' training to implement interactive technologies. (Doctoral dissertation). Uman, Ukraine.

4. Kukushkin, V. S. (Ed.). (2004). Pedagogical technologies: manual for students of pedagogical specialties. Moscow, Russia: IKTs "MarT".

5. Lypchanko-Kovalchyk, O. V. (2016). Future bachelors-philologists to implement interactive technologies in their professional activities. ( $\mathrm{PhD}$ dissertation). Rivne, Ukraine.

6. Nikolaieva, S. Yu. (2002). Methodology of teaching foreign languages at secondary schools. Kyiv, Ukraine: Lenvit.

7. Pometun, O. I. \& Pyrozhenko, L. V. (2004). Modern lesson: interactive technologies of learning. Kyiv, Ukraine: A.S.K.

8. Sysoieva, S. O. (Ed.). (2001). Pedagogical technologies in continuing professional education. Kyiv, Ukraine.

Матеріали надійшли до редакції 04.12.2018 р. 